\title{
The Conservative Party and the impact of the 1918 Reform Act
}

\author{
Stuart Ball
}

University of Leicester

\section{abstract}

Before the First World War, the Conservative Party feared the extension of the suffrage to all adult males, and was divided over even a limited granting of votes to women. However, the patriotic public response to the war moderated these attitudes, and by 1916 the Conservatives were in favour of giving the vote to all servicemen. Although the Conservatives were represented in the Speaker's Conference which drew up proposals for electoral reform, when its report was published in January 1917 these were almost entirely opposed by the party organisation. However, the Conservatives came to accept adult male suffrage as the only practicable way of recognising the servicemen's contribution. During the passage of the electoral reform bill, they successfully amended it in several respects and secured gains from the redistribution of constituencies. This article assesses the Conservative response to the reform proposals and the impact of the Representation of the People Act 1918 upon the party's fortunes, organisation and culture. During the following decade, the Conservative Party made substantial efforts to reach the female, younger and working-class voters. Whilst it was reassured by electoral success, and especially support from women, there remained concerns about the nature of democracy and demands from the grass-roots for a defensive restoration of powers to the House of Lords. However, by 1928 giving the vote to women on equal terms of adult citizenship was seen as the inevitable completion of the new electoral system - in which the Conservatives became the most successful party.

\section{keywords}

Representation of the People Act 1918

Conservative Party

electoral reform

franchise

female suffrage

proportional representation

redistribution

House of Lords

Andrew Bonar Law

Equal Franchise Act 1928

The Reform Act passed in 1918 (formally titled the Representation of the People Act) was by far the most extensive expansion in the political nation of any franchise measure, and the dozen years after it 
took effect saw the only substantial and long-term change that has taken place in the British party system. The collapse of the Liberals as a governing party, their replacement on the left by the rise of Labour, and the re-establishment of the Conservative Party ${ }^{1}$ as the most successful securer of power, was (like the Reform Act itself) mainly caused by the First World War, but the transformation of the electoral system also made a significant contribution. Even if the 1918 Reform Act was more the conduit of change than its cause, post-war developments would have had different contours if the act had taken a different form. This article examines its impact on the Conservative Party - the party of established authority, social hierarchy, privilege and property which might be thought the most vulnerable and unappealing to mass citizenship-based democracy. Instead, it was to prosper the most in the new environment, and generally has continued to do so throughout the century since 1918 winning the most seats in 17 of the 27 general elections that have taken place between 1918 and 2017, and being the sole government or the largest party in a coalition for just over two-thirds of the last hundred years.

During the decade before the outbreak of the First World War, the most contentious issues between the Conservative and Liberal parties were the protectionist programme of 'tariff reform', the powers of the House of Lords, and the prospect of the passage of Home Rule for Ireland. However, alongside these were differences on other matters, including electoral reform - particularly the Liberals' wish to curtail plural voting, the Conservatives' objections to the over-representation of Ireland, and the complexities for both parties in responding to the increasingly prominent but problematic question of votes for women. Conservative attitudes towards the latter were far from monolithic, and whilst the majority of those who vehemently opposed any measure of female enfranchisement were Conservatives, complete negation was not the position of the majority of the party. $^{2}$ There was a spectrum of opinion ranging from the inflexible 'antis' to active suffrage campaigners, such as Lady Knightley and Lady Selborne, who were organised in the Conservative and Unionist Women's Franchise Association. ${ }^{3}$ Although there was a reaction against the violence of the militant suffragettes, support for giving votes for women on same property basis as men was growing amongst both the leadership and MPs, though less so amongst peers. ${ }^{4}$ Many Conservative MPs took a pragmatic attitude to the question of votes for women, and viewed it mainly in the context of the possible introduction of full adult male suffrage, which they generally assumed would be detrimental to their interests.

Conservative responses were more uniform, negative and defensive on other aspects of electoral reform. This was simple enough in the case of plural voting, where an elector might qualify for additional votes due to the ownership of property in another constituency from the one that they resided in, or if a graduate might have a vote in one of the university seats. By their nature, the plural franchises were the preserve of the wealthier strata of society, and all observers were agreed that a large majority of these votes were given to the Conservatives. Although the 'out-voters' were generally a small proportion of the electoral roll, in a number of urban and marginal constituencies they were enough to swing the result in Conservative favour - and hence the wish of the Liberal and

1 The term Conservative is used in this article for clarity, although the customary name used by the party from the early 1890 s to the early 1920 s was Unionist. The latter derived from the centrality of defending the union with Ireland as a political issue after 1886 and the alliance with the Liberal Unionists; the latter was formalised by merger in 1912, after which the official name became 'Conservative and Unionist'.

2 G.E. Maguire, Conservative Women: A History of Women and the Conservative Party 1874-1997 (1998); L. Maguire, 'The Conservative Party and women's suffrage', and P. Vervaecke, 'The Primrose League and women's suffrage 1883-1918', in Suffrage Outside Suffragism: Women's Vote in Britain 1880-1914, ed. M. BoussahbaBravard (2007), 52-76,180-201.

3 For the opponents, see B. Harrison, Separate Spheres: The Opposition to Women's Suffrage in Britain (1978), and J. Bush, Women Against The Vote: Female Anti-Suffragism in Britain (Oxford, 2007); for Conservative suffragism, see M. Auchterlonie, Conservative Suffragists: The Women's Vote and the Tory Party (2007).

4 M. Pugh, The March of the Women: A Revisionist Analysis of the Campaign for Women's Suffrage 1866-1914 (Oxford, 2000), 102-19. 
Labour parties to abolish them, and the Conservative determination to keep them. In 1912 and 1913, bills to abolish plural voting were passed in the house of commons, but rejected by the Conservative majority in the house of lords.

As in so many other aspects of British politics, the First World War produced transformative changes - not at first, but as a consequence of the conflict's continuation and the increasing demands that it placed upon the nation. The mass enthusiasm for enlistment in the army in 1914-15 and the public acceptance of the introduction of conscription in 1916 changed attitudes towards the expansion of the franchise to full manhood suffrage. Lord Selborne, one of the party leaders, wrote in August 1916 that 'the way that the men of our race have behaved in this war has made adult manhood suffrage inevitable; we shall have to do in one stage what I should have preferred to do in several'. ${ }^{5}$ The evident sense of duty and the sacrifice of the young men serving in the armed forces created a consequent entitlement, but under the existing system many of those who enlisted did not qualify for the vote, as the franchise was conferred upon householders and ratepayers, who tended to be older; there was also no mechanism by which those who were serving overseas - or at sea - could cast their vote even if they had one. It had been decided in 1915 to postpone the preparation of the electoral register, and by the time that the issue was returned to in 1916 there was widespread acceptance by politicians in all parties that the contribution of the servicemen must be recognised by extending the male franchise. Whilst many Conservatives would have preferred to limit this to those serving in the armed forces, in practice there was no means of doing so that did not raise more issues than it resolved. As the party leader, Andrew Bonar Law, explained at a special party conference in November 1917 (the only one held during the war): ${ }^{6}$

Once we had the whole nation practically fighting for us, it was obvious that these men must have votes (Hear, hear and applause) If you start with that hypothesis it is very difficult to see - I never could see how you could stop much short of the Bill which is now before the House of Commons.

In consequence, with some reluctance, manhood suffrage became accepted as the price of obtaining the vote for servicemen, which by late 1916 Conservatives at all levels considered necessary and desirable. $^{7}$ Additionally, once extending the male franchise became accepted, for most Conservatives this removed the barrier to granting votes for women in at least some form.

It was in this context that Walter Long, one of the Conservative Party's leading figures and, as President of the Local Government Board, the minister overseeing electoral registration, believed that there was a unique opportunity for consensus, and in August 1916 he proposed an inter-party conference. ${ }^{8}$ This was established in the following month when the Speaker of the House of Commons, James Lowther, agreed to become its chairman and selected as its members 27 backbench MPs and five peers who reflected a balanced range of opinion. The conference met 26 times between 12 October 1916 and 26 January 1917; Lowther's approach was designed to find the common ground as quickly as possible, and only after that tackle the more contentious points; the result was that all the participants felt that they were gaining some part of their objectives, and so confrontation was minimised and a breakdown prevented. The proceedings took place in secret and there is no record of them, but it seems clear that there was a compromise between the Conservatives and Liberals, in

Earl of Selborne to marquis of Salisbury, 25 Aug. 1916, in The Crisis of British Unionism: The Domestic Political Papers of the 2nd Earl of Selborne 1885-1922, ed. D.G. Boyce (1987), 194-5.

6 Bodl., Conservative Party Archive (hereafter CPA), NUA/2/1/35, National Unionist Association (hereafter NUA) special conference, 30 Nov. 1917.

7 N. Keohane, The Party of Patriotism: The Conservative Party and the First World War (Farnham, 2010), 131-9.

$8 \quad H C$ Deb., fifth series, lxxxv, col. 1949, 15 Aug. 1916; J.D. Fair, British Inter-Party Conferences: A Study of the Procedure of Conciliation in British Politics, 1867-1921 (Oxford, 1980), 170-2. 
which the former accepted adult male suffrage and the latter accepted the retention of some plural voting and a redistribution of constituencies. A majority of the conference recommended the inclusion of female suffrage in a more limited form (their report suggested an age limit of 30 or 35, leaving it to parliament to decide) and, more surprisingly, there was a unanimous proposal for the introduction of proportional representation.

The eventual outcome of the conference's recommendations would turn out to be more beneficial for the Conservatives than their opponents, but initially many MPs, the party organisers and the grassroots did not see it in that light at all. The secretary of the constituency association in Bath gave his executive committee a bleak summary: 'the recommendations ... will be fatal to the Conservative Party, and that any hope that might have been entertained of their coming into office soon would be swept away into the dim and distant future.' 9 Ominously, the influential Sir Edward Carson, recently appointed a cabinet minister in Lloyd George's new coalition, circulated a petition against the report which was signed by over a hundred Conservative MPs. ${ }^{10}$ The outgoing Chairman of the Party Organisation, Sir Arthur Steel-Maitland, wrote to Long on 3 February that the proposals were 'absolutely disastrous',' and the view of the party's professional local agents was that the Conservative members of the conference had been outmanoeuvred by their Liberal counterparts, partly through failing to seek expert advice. ${ }^{12}$ The executive committee of the National Unionist Association, the body of the voluntary membership, appointed a sub-committee to go through the proposals, and its report was strongly critical. ${ }^{13}$ Not unnaturally, it focussed more on what was being definitely conceded than on what might be hypothetically gained. There were concerns about so sweeping an extension of the male franchise in the middle of a major war, whilst the redistribution of seats which Conservatives had pressed for before the conflict might now produce very different - or at least, unpredictable - results with such a broadened and possibly radicalised electorate. ${ }^{14}$ By early May, the Central Office reported that 81 constituencies had sent resolutions or letters against the bill and only four in favour; although in 56 cases the reason given for opposition was that such a measure should not be dealt with in wartime, rather than its provisions, that may also have been the easiest way of saying that it should not be tackled at all, or not in this way. ${ }^{15}$ Of those expressing a more specific opinion, 15 constituencies had opposed proportional representation (none being recorded in favour), ${ }^{16}$

Bath \& North-East Somerset Record Office, Acc. 12, Bath Conservative Association (hereafter CA), special executive committee, 22 Feb. 1917.

Parliamentary Archives [hereafter PA], Lloyd George MSS, LG/F/6/2/19, Sir E. Carson to D. Lloyd George, 8 Mar. 1917; Fair, British Inter-Party Conferences, 177.

11 Wiltshire \& Swindon Archives, Long MSS, 947/675, Sir A. Steel-Maitland to W. Long, 3 Feb. 1917; National Records of Scotland, Steel-Maitland MSS, GD193/202, memo by Steel-Maitland, 'Notes on the Report of the Speaker's Conference', 3 Feb. 1917.

12 Conservative Agents' Journal, Apr. 1917, 54, 59-61.

13 CPA, NUA/4/1/2-3, NUA executive committee, 8 Feb., 13 Mar. 1917; NUA/6/1/1, NUA executive sub-committee to consider electoral reform, 20 Feb. 1917.

14 Bradford Record Office, 36D78/14, Bradford CA, finance \& general purposes committee, 19 June 1917, J. Fawcett to Sir J. Boraston (Principal Agent).

15 Sheffield Central Library, LD2103, Sheffield Central CA, special meeting, 20 Feb. 1917. Lord Derby told the party leader that the Lancashire Provincial Division was 'very much opposed to the Speaker's proposals': PA, Bonar Law MSS, BL/81/6/13, earl of Derby to A. Bonar Law, 15 May 1917.

16 This balance of opinion is reflected in the surviving city and constituency association minute books, with several hostile resolutions and only one favourable view, but even here opinion was divided and only narrowly came down in favour: Sheffield Central Library, LD2107, City of Sheffield CA, annual general meeting, 27 Mar. 1918. This is a notably different pattern from the Conservative-supporting national press, who were strongly in favour of proportional representation throughout the passage of the bill: see the editorial columns of the Daily Telegraph, Observer and The Times. 
whilst of the 15 that had given a verdict on female suffrage, nine had approved of it and six were against. $^{17}$

Reflecting these rising concerns, in mid-April the executive committee urged the party leaders to take a completely different course. Their plan was 'to re-establish registration on a normal basis' by means of 'a new Register to be prepared in the normal way under the existing Law', but with the inclusion of servicemen based on whatever qualification they had before enlisting, and that 'munitions workers should be provided for in the same way or by shortening the qualifying period' (the latter point was because many of these workers had moved to where the new factories had been established). ${ }^{18}$ However, the leadership was aware that this was no longer a tenable position in the wake of the Speaker's Conference report and in the context of both parliamentary and public opinion. On 28 March, the house of commons had approved Asquith's motion accepting the report and calling for legislation based upon it to be promptly introduced by 341 to 62 , with all of the latter being Conservatives. $^{19}$ Bonar Law later explained at the special party conference of November 1917, in reply to a question as to why the simpler procedure of a registration bill amended to include servicemen had not been followed, that 'you have to look at things as they were in the House of Commons'; such a measure would have been open to amendments from all sides, and 'it would have been impossible to get through the trouble that would have been raised'. A limited male enfranchisement was not practicable, and he called upon his audience not just 'to make the best of the situation which has arisen', but to seize the opportunity 'to make our party what Disraeli called it and what, if it is to have any existence, it must be - a really national party. ${ }^{20}$

This was more than a pious hope; the war had demonstrated the loyalty of the working class and had strengthened patriotic and national feeling, with the latter shifting the political centre of gravity in a rightwards direction. This in turn fostered the Conservative Party's sense that it was in tune with public opinion; as the chairman of the party conference of November 1917 declared in his opening remarks, 'the note of patriotism has always resounded through the length and breadth of our ranks'. ${ }^{21}$ On the only national issue that mattered in 1917 and 1918 - the vigorous and unconstrained prosecution of the war to achieve decisive victory - this was the case to an extent that could not be matched by either the fractured Liberals or the Labour Party, with its highly-publicised wing of doubters and critics who were pilloried as supposed 'pacifists'. Whilst there were certainly Conservative fears about the growing strength and militancy of the labour movement, and its evolution in a Socialist, syndicalist and perhaps even revolutionary direction, these were outweighed (although not removed) by the conviction that the large majority of the working class were dependably patriotic. By mid-1917, there was acceptance that the war had made political change inevitable, and that following the February revolution in Russia and the entry of the United States in April, 'the very war itself is now a war of democracy against autocracy', which 'must have a direct bearing on the policy of the [Conservative] party'. ${ }^{22}$ Trust in the people became not just a viable strategy, but the best means of assuring social stability and national cohesion. As Bonar Law told the special conference,

17 CPA, NUA/4/1/3, NUA executive, 8 May 1917.

18 CPA, NUA/3/1/1, NUA report of executive to central council, 17 Apr. 1917

19 Different voting figures for the divisions during the passage of the bill are given in various books and articles; some variations are due to errors, but generally in the case of Commons divisions the discrepancies are due to whether or not the two tellers on each side are counted as having voted. The division list figures here have been checked with the official record of debates and are the ones given there, which in the case of the house of commons do not include the tellers, as technically they have not voted in the lobby which they counting. 
'our Party if it is properly conducted has no reason to fear that the mass of the people in this country will not support it'. ${ }^{23}$

The formal first reading of the Representation of the People bill in the house of commons took place on 15 May 1917 without a division, and on 23 May the second reading was passed by 329 to 40. Whilst all of those voting against were Conservatives, it was more significant that 110 Conservative MPs supported the bill; this also showed the evolving balance of opinion since Asquith's motion of 28 March, which had been opposed (including the tellers) by 64 Conservatives and supported by 79 . By early June, as the bill entered the committee stage of detailed debate, the Conservative Party had generally come to accept the inevitability of substantial reform, especially if the key element of votes for servicemen was to be achieved. ${ }^{24}$ This position had not been attained without management and effort; the Conservative party chairman informed Lloyd George regarding 'the Franchise Bill' that 'Bonar Law will be able to tell you by what a narrow squeak I managed to secure acceptance of the general principles of that measure'. ${ }^{25}$ Thus the central council, the largest body representative of the constituencies, in 'not too easy a meeting to guide', ${ }^{26}$ on 8 June unanimously approved the report of the executive's sub-committee, which with some simplification of past history declared that the Conservative Party 'has always been in favour of ... an extension of the franchise', although this was conditional upon it being accompanied by a redistribution of constituencies and a restoration of powers to the House of Lords. ${ }^{27}$ However, whilst the main provisions of the bill were now accepted, Conservative party managers certainly did not embrace the measure in all its aspects. ${ }^{28}$ There was much that could be adjusted in defence of the party's interests, and in preparation for this a new subcommittee of the National Unionist Association executive was established on 22 May. $^{29}$ Led by the chairman of the party organisation, Sir George Younger, it included the joint principal agents and several prominent members of the executive, and was advised by a group of experienced constituency agents; its role was to consider 'in what direction amendments should be made' and give advice to the MPs moving them. ${ }^{30}$ Over 150 amendments were tabled, and in several cases the minister in charge of the bill, the home secretary, Sir George Cave, was forced to concede a free vote and the amendment was carried.

One of the latter was important for its symbolism rather than the relatively small number of voters that were affected. The disenfranchisement of conscientious objectors was a topic about which Conservatives felt strongly; it was not amongst the proposals of the Speaker's Conference, but was inserted after an amendment moved by Younger was passed in a free vote by 209 to 171 on 21 November $1917 .^{31}$ This was not a matter of the number of conscientious objectors, which was

23 CPA, NUA special conference, 30 Nov. 1917; National Library of Scotland, 10424/28, Scottish Unionist Association, western divisional council, 28 Feb. 1917.

However, in some areas expressions of opposition continued for some time; in late June, the Yorkshire Area unanimously passed a resolution that 'The Franchise Bill at present before Parliament is in most of its essential features in direct conflict with the views of the [Conservative] Party in Yorkshire': Leeds Archives, Yorkshire Area, council, 29 June 1917.

PA, Bonar Law MSS, BL/82/1/10, Sir G. Younger to Lloyd George, 8 June 1917.

PA, Bonar Law MSS, BL/82/1/11, Younger to Lloyd George, 9 June 1917.

CPA, NUA/3/1/1, NUA central council, 8 June 1917, 'Electoral Reform "Representation of the People Bill”, Report of the Sub-committee to the Executive Committee'.

Keohane, Party of Patriotism, 137-42.

CPA, NUA executive, 22 May 1917.

CPA, NUA/6/1/1, NUA executive sub-committee to consider the Representation of the People Bill, 24 \& 25 May, 1 June 1917; NUA executive, 7 June 1917; NUA report of executive to central council, 10 July 1917; Conservative Agents' Journal, July 1917, report of special registration committee, 147-9; M. Pugh, Electoral Reform in War and Peace 1906-18 (1978), 105-6.

31 This was first proposed in an amendment moved by the Conservative MP Ronald McNeill during the committee stage on 26 June 1917, which was defeated in a whipped vote; it probably originated from the NUA executive sub- 
insignificant even on the pre-war franchise, but because of what they represented - to Conservatives, and it must be said to many others as well, the pacifists had failed the test not just of patriotism but more basically of citizenship, having placed their personal moral purity above the safety of the community. They were therefore not entitled to exercise the privileges of that citizenship, and to allow them to do so would be an insult to the fallen and an affront to the living servicemen who had fulfilled their duty. Although the numbers were vastly different, there was a direct relationship of principle between giving the vote to servicemen and taking it away from pacifists.

The most important changes for the Conservatives were in two areas. The first of these was the defence of the agricultural interest, with which the party was traditionally linked and which generally supported it. As well as a likely reduction in the number of agricultural seats due to their lower population, there was concern that their rural nature would be diluted as a consequence of the smaller boroughs losing their separate representation and being absorbed into the neighbouring county divisions. On 18 June 1917, Conservative support secured an amendment of the instructions to the boundary commissioners, so that the scale and economic composition of a constituency would be taken into account as well as its population. ${ }^{32}$ This was intended to avoid the rural constituencies from becoming unmanageable in physical size, and thereby retain a larger number of them. The second area was the business premises franchise, which the original proposals for proportional representation would have rendered useless in the cities - the very places where it was most numerous and effective. The abandonment of the scheme for large multi-member borough constituencies using the single transferable vote did much to restore the efficacy of the business franchise. In addition, an amendment was carried in November 1917 under which a voter resident in one constituency of a town or city which was divided into separate single-member seats could qualify for the business vote in another constituency within the same town or city; thus, a factory owner or shopkeeper who lived in Newcastle North and occupied business premises in Newcastle Central could now cast a vote in both, which had not been the case previously. The 1918 Reform Act limited the ways in which people could qualify for an additional vote, and this considerably reduced the number of plural votes from the pre-war level in England and Wales of 450,000-475,000 to 159,013 in 1918 and 211,257 in 1924; ${ }^{33}$ the act also introduced a new restriction that no one could cast more than two votes in total, even if they might qualify for more. ${ }^{34}$ However, enabling the use of the business vote within the same divided town or city made it more useful and more likely that it would be cast, and this was certainly advantageous to the Conservative Party. ${ }^{35}$

The main controversy as the bill proceeded through its stages was the proposed introduction of proportional representation, by means of creating constituencies in the cities and largest towns which would return between three and five MPs using the single transferable vote system. Whilst it might be thought that this would benefit the Conservatives where their support was a minority, in practice the partioning of the cities into individual divisions by the Third Reform Act in 1885 had often worked well for them. ${ }^{36}$ In several cities, the party had been able to win a high proportion of the seats through effective organisation and the assistance of the business vote. In this context, proportional

committee to consider the Representation of the People Bill, which on 24 May 1917 considered 'that Conscientious Objectors ought to be disfranchised'; see also Pugh, Electoral Reform, 113-14, 125-6.

Sanders diary, 10 \& 15 June, 20 July 1917, in Real Old Tory Politics: The Political Diaries of Sir Robert Sanders, Lord Bayford: 1910-1935, ed. J. Ramsden (1984).

D. Tanner, Political Change and the Labour Party 1900-1918 (Cambridge, 1990), 100; British Electoral Facts 1832-1987, ed. F.W.S. Craig (Aldershot, 1989), 78

In fact, very few did so; Central Office estimated that only around 2,000 men had four or more votes: Steel-Maitland MSS, GD193/202, memo by W. Gales, Oct. 1916.

35 Sanders diary, 22 Nov. 1917; J. Ramsden, The Age of Balfour and Baldwin 1902-1940 (1978), 121.

36 See Table 4 in the Introduction to this volume. The NUA executive sub-committee 'were strongly of opinion that single member constituencies were to be preferred': NUA executive sub-committee to consider electoral reform, 24 Feb, 1917. 
representation could only undermine the party's position; hence the vehemently hostile response from Liverpool, where the Conservatives had won eight of the nine seats in December 1910, whose leaders painted an apocalyptic scenario and threatened to resign if proportional representation was applied to it. $^{37}$ However, the prime minister, Lloyd George, had indicated his lack of support for proportional representation in the original debate on the Speaker's Conference report on 28 March $1917,{ }^{38}$ and this made it easier for Conservatives to oppose it without seeming to be partisan or disloyal to the government.

Some Conservatives favoured the single transferable vote as the means by which a moderate majority of opinion could block Socialist or even revolutionary extremism, or more pessimistically as the way of retaining some representation in the cities from being swept away by a working-class Labour tide under adult suffrage; these views were held more widely in the house of lords than the commons, and led to disagreement between the two houses during the final stages of the bill. ${ }^{39}$ However, many Conservative MPs were opposed to the single transferable vote, and even more strongly to the alternative vote, because they expected - probably correctly, given the pre-war LiberalLabour pact - that in both systems the second preferences of Liberal and Labour voters would be given to each other, with the result that the Conservatives would be defeated in seats which in a threeway contest under the first-past-the-post system they would win. Other objections to proportional representation included the unworkable size of the multi-member constituencies that were required for it to work effectively, and the view that it would increase rather than diminish the dependency of candidates on the party machine for selection and election. One critical constituency resolution observed that 'Members of Parliament should be in close relation with their constituents; they are responsible not to their political partisans only but to the whole of the electors. Under PR this will be lost. ${ }^{40}$

Whilst there were also a considerable number of Liberal MPs who were dubious about or felt threatened by the single transferable vote scheme, the pattern of party attitudes was apparent in the votes at various stages during the passage of the bill. Proportional representation was first defeated during the committee stage of the bill on 12 June 1917, when a resolution amending the instructions to the boundary commissioners to proceed on the basis that it would not be implemented was passed by 149 to 141 , with 85 Conservatives amongst the majority and only 38 in the minority. Subsequently, the alternative vote was approved twice during the bill's passage, although on 9 August this was by the margin of just a single vote: 125 MPs (including only two Conservatives) voted in favour, whilst 124 (of whom 111 were Conservatives) voted against. ${ }^{41}$ It was approved by the much larger margin of 150 to 121 during the report stage on 22 November (when the single transferable vote was again defeated), but when the bill was considered in the house of lords in January 1918, the Conservativedominated upper chamber three times removed the alternative vote and replaced it with the single transferable vote. The Lords' amendments were rejected on each occasion by the house of commons, leading to a brief confrontation between the two chambers. In the end, a compromise was agreed under which both the alternative vote and the single transferable vote were dropped from the bill, and so the final form of the Representation of the People Act which received the royal assent on 6

37 PA, Bonar Law MSS, BL/83/3/2, BL/83/3/12, C. Petrie \& A. Salvidge to Bonar Law, 1 \& 3 May 1918; this was in response to the scheme proposed by the Royal Commission set up by the Act, which reported in April 1918.

38 HC Deb., fifth series, xcii, col. 492, 28 March 1917. A similar view, that 'its disappearance would in no way disturb the other parts of the structure', had been expressed in the long letter supporting the conference proposals from 'Unionist MP' in the Daily Telegraph, 8 Mar. 1917.

Sanders diary, 10 Feb. 1918; for a discussion of varying Conservative responses, within and between both houses, see Pugh, Electoral Reform, 158-67; J. Hart, Proportional Representation: Critics of the British Electoral System 1820-1945 (Oxford, 1992), 182, 186-7, 190-1; Keohane, Party of Patriotism, 142-3.

41 HC Deb., fifth series, xcvii, col. 652, 9 Aug. 1917; the figures published in The Times, 11 Aug. 1917, 7, included the two tellers on each side, who were two Conservatives for the 'No' vote and two Liberals for the 'Aye' vote. 
February 1918 retained the existing first-past-the-post system everywhere, except for the four university constituencies that returned two or more MPs. ${ }^{42}$ The Conservative peers certainly assisted their party's prospects by securing the elimination of the alternative vote; whilst David Butler's estimates of the outcomes of the general elections from 1923 to 1945 if it had been operating give results almost as large for the three big Conservative victories of 1924, 1931 and 1935, the projection for the three defeats is much poorer. In 1923, the Conservatives with 195 MPs would have been one behind Labour and the Liberals would have been the largest party with 217 MPs, with the incalculable consequences of a Liberal government and the potential stemming of that party's decline; in 1929, Labour would have been very close to an overall majority, with 301 MPs to 167 Conservatives (nearly a hundred less seats than they won under first-past-the-post) and 137 Liberals, and in 1945 Labour would have had 32 more MPs than their actual landslide, and the Conservatives at 171 over forty fewer, which would have given them a harder task in recovery. ${ }^{43}$

The 1918 Reform Act contained more provisions that were advantageous to the Conservative Party than those that were detrimental, although there were initial fears about several aspects and the benefits only became apparent over time. The area of greatest concern and potential danger was the extension of the male franchise to include almost all adults, and the fear that the wartime expansion of trade unionism, the other economic and social effects of the war, and the ending of the disqualification from voting of those who had been in receipt of Poor Law relief would mainly benefit the Labour Party, who "will have a majority of voters throughout the whole of the country'. ${ }^{44}$ This was a particular concern of Conservatives in industrial areas, and the chairman of the party in Liverpool - a key location in a key region for the Conservatives - sent a pessimistic assessment of the future consequences to the party leader in the autumn of $1917 .{ }^{45}$ More generally, the expert advice given to the National Unionist Association executive's sub-committee in February 1917 was that the new male voters resulting from the change to a simple residence qualification would probably be against the party in the proportion of six to four. ${ }^{46}$ Concern about the loyalty and stability of the industrial working-class was fanned by the increase in strikes in 1917-18, but was also partly offset by confidence in the patriotic attitudes of the servicemen. ${ }^{47}$

When the war came to an end, rather unexpectedly quickly, with the Armistice of 11 November 1918, this removed the justification for further extensions of the parliament that had been elected in December 1910. This was also Lloyd George's opportunity to consolidate his position and secure a personal mandate before the peace negotiations. The popularity of the 'man who won the war' was certainly a factor in the decision of the Conservative leaders, which was endorsed by a meeting of the parliamentary party, to continue the coalition into peacetime and contest the imminent general election in alliance with Lloyd George and his wing of the Liberal Party. However, the other key element in this decision was concern about the potential volatility of the new electorate and uncertainty about how it would behave, especially in the context of industrial militancy at home and spreading Bolshevik revolution in central and eastern Europe. In fact, the transformation of the electorate, in which many men as well as women would be casting a ballot for the first time, was not as great a

42 As part of the compromise, the Act contained the provision that a royal commission would be appointed to draw up a proposal for the application of the single transferable vote in seats that would in total return around 100 MPs; this was published on 13 April 1918 but rejected by the house of commons on 13 May.

D. Butler, The Electoral System in Britain 1918-1951 (Oxford, 1953), 191.

CPA, NUA special conference, 30 Nov. 1917, speech by Lord Chaplin.

PA, Bonar Law MSS, BL/82/5/7, Petrie to Bonar Law, 13 Oct. 1917.

NUA executive sub-committee to consider electoral reform, 20 Feb, 1917.

Ramsden, Age of Balfour and Baldwin, 115-17. 
danger for the Conservatives as the overall numbers suggested. Before 1914, the rural areas and country towns with their more settled populations had higher proportions of male enfranchisement than was the case in the industrial towns and the cities, with some agricultural counties reaching an average of $81 \%{ }^{48}$ With male enfranchisement in 1918 of around $95 \%$ in these areas, the increment was relatively modest in that gender and most of the new voters were women, to whom the Conservative Party was able to project an inclusive appeal. Many of these areas already returned Conservative MPs and continued to do so in the new democracy, and other similar constituencies followed this pattern as the Liberal Party declined.

The restrictions on female suffrage tilted that electorate in directions likely to be more favourable to the Conservatives, particularly by excluding younger women. This was partly due to the proportion of Conservative support increasing in older age groups, a pattern which has been observed over a long period and still applies, and partly to the economic and social structure of the inter-war period. Many working women - the group most likely to come into close contact with trade unionism and the Labour Party - were too young to vote under the 1918 Reform Act; of the 3,671,596 women aged over 20 which the 1921 census recorded in occupations, 1,060,058 (28.9\%) were 20-24, and 1,051,191 $(28.6 \%)$ were in the next age band of 25-34; if it is assumed that half of the latter were aged 25-29, then $43.2 \%$ of working women were under the qualifying age of 30 . Most women left work on marriage, which was usually by their mid-20s and soon followed by motherhood. According to the 1921 census, $72.6 \%$ of women aged 20 to 24 were single, whilst $78.5 \%$ of women aged over 25 were either married or widowed; the latter groups also comprised $90.2 \%$ of the women over 25 who were not in occupations outside the home. ${ }^{49}$ In the inter-war period, the Conservative Party pitched its appeal to female voters primarily to the married woman, based upon the cross-class values of home and family, and in contrast to the masculine (often misogynistic) and confrontational environment of the workplace. Women were expected to take a common sense approach and be less attracted to Socialist theories, and married women were assumed to put their family interests first. This was thought to be particularly the case in the working-class, where they would exert a moderating influence upon their trade unionist and Labour-supporting husbands. Conservative propaganda in the 1920s often portrayed the working-class wife and mother (or an older experienced working-woman) as seeing through the false rhetoric of the Socialist agitator and preventing destructive industrial conflict. ${ }^{50}$ The property restriction on female suffrage was of less assistance than the age limit, and may even have been disadvantageous to the Conservative Party. The largest single category of women aged over 30 who did not qualify for the vote after 1918 were domestic servants, of whom there were nearly half a million in the early 1920s. ${ }^{51}$ These women may have been most likely to identify with the opinions or economic interests of their employers, and certainly were least likely to be members of trade unions or be living in the poorest districts of towns and cities (although they may well have had relatives who were).

The retention of plural voting was certainly of most help to the Conservative Party (and the least help to Labour); the new limitation to using only two votes was not a very significant handicap, as in most cases practicality made casting any more difficult to manage. Contemporary observers had no doubt that the business vote was overwhelmingly Conservative. At the time of the 1931 census, there were 21 constituencies where the non-resident voters comprised more than five per cent of the

\footnotetext{
$48 \quad$ W.L. Miller, Electoral Dynamics in Britain since 1918 (1977), 3.

49 Census of England and Wales, 1921: Occupation Tables (1924), 54.

50 D. Jarvis, 'Mrs Maggs and Betty: the Conservative appeal to women voters in the 1920s', 20th Century British History, v (1994), 129-52.

51 In census category 900, 'Domestic Servants - Indoor', there were 357,707 women aged over 35 and 234,567 aged 25-34; if it is assumed that half of the latter were 30-34, this gives a total of 474,990: Census of England and Wales, 1921: Occupation Tables (1924), 104.
} 
electorate, ${ }^{52}$ and a further 37 where they were more than two percent; sometimes, this was more than the winning candidate's majority. In the first category, which comprised 22 parliamentary seats as it included the double-member City of London, out of the 154 possible wins in the seven inter-war general elections of 1918-35, the Conservative candidate was elected on 104 occasions, a success rate of $67.5 \%{ }^{53}$ The other form of plural voting, the university seats, continued to be of much more benefit to the Conservatives than any other party. Of the twelve university seats in England, Wales, Scotland and Northern Ireland, in the general elections from 1918 to 1935, the Conservative Party normally won eight or nine of these, with Liberals and independents accounting for the rest, and no success for the Labour Party (see the table in the Introduction). ${ }^{54}$ In view of these advantages, it is not surprising that the first Labour government to enjoy a parliamentary majority abolished both the business vote and the university seats in the 1948 Representation of the People Act.

Several of the other provisions in the 1918 Reform Act were either marginally helpful or mainly neutral in their impact upon Conservative MPs and the party organisation. Whilst its candidates were recruited from the small minority of the wealthier strata of society, the expectation that they would personally not only pay their election expenses but also give a substantial annual subscription to their constituency association (often as much as the MPs’ salary of $£ 400$ per annum) placed strains on the pockets of many in the upper-middle and even upper class, especially in the post-war era of greatly increased taxation and economic difficulty. This led to the safest seats being effectively auctioned to the highest bidder by choosing their candidates on their wealth rather than their ability, a problem that was often denounced in the inter-war era but only finally tackled in the Maxwell-Fyfe Report of 1949. Thus, the lower limit on election expenses in the 1918 Reform Act was generally welcome to Conservatives, as there was an inevitable tendency (and even an expectation from their associations) of spending up to whatever the limit was. On the other hand, finding the money for the new requirement of the candidate's deposit of $£ 150$ was not a problem - it was not only much less than the election expenses, which could be around $£ 800-900$, but not getting it back was a rare event for a Conservative - of the party's 3,753 candidates in the general elections from 1918 to 1935, only 29 $(0.8 \%)$ forfeited their deposit. The free postal delivery helped to keep down expenses and was useful, as it was 'frequently the only way in which a communication from the candidate can reach isolated voters'. ${ }^{55}$ However, this and the free use of school rooms for meetings was of most assistance to the candidates with the least financial resources, and generally they were not the Conservatives. The provision that all constituencies polled on the same day placed a practical restriction on the use of the business premises vote, but this had much less impact as plural voting was now limited to casting only one extra vote, and it was more than outweighed by the new ability to use the second vote in a constituency that was part of the same borough or county.

52 These were the business and central districts of the larger cities, and in descending order: City of London (83.9\%), Manchester Exchange (31.6\%), Holborn (30.5\%), Westminster Abbey (27.7\%), Liverpool Exchange (27.8\%), Leeds Central (12.0\%), Finsbury (11.8\%), Sheffield Central (11.3\%), Bradford Central (9.9\%), St Marylebone (9.6\%), Birmingham Edgbaston (9.3\%), Newcastle Central (9.2\%), Birmingham West (8.3\%), Bristol Central (8.3\%), Westminster St George's (7.8\%), Hull Central (7.2\%), Shoreditch (7.2\%), Southwark North (6.6\%), Nottingham Central (6.4\%), Whitechapel \& St George's (6.3\%), and St Pancras South-West (5.8\%); figures from the election and census database constructed for S. Ball, Portrait of a Party: The Conservative Party in Britain 1918-1945 (Oxford, 2013), see Appendix ii.

53 Only official Conservative candidates have been counted. This figure probably under-estimates Conservative strength, as in four of the constituencies no Conservative candidate was nominated in 1931 and 1935 against sitting National Labour or Liberal National MPs; if these eight contests are removed from the possible wins, the Conservative success rate becomes $71.2 \%$. David Butler estimated the number of seats won due to the business vote in the general elections of 1922-35 as between the lowest probability of 43 and the highest probability of 75 , an average of 7-12: Butler, Electoral System in Britain 1918-1951, 148.

54 There was a dip to seven Conservatives in 1935 because three Independents were elected under the 'National' label; J.S. Meisel, Knowledge and Power: The Parliamentary Representation of Universities in Britain and the Empire (Oxford, 2011), 73-8.

55 Conservative Agents' Journal, Oct. 1920, 10. 
The one reform for which Conservatives had unitedly and whole-heartedly pressed before 1914 was the redistribution of constituencies. There were two aspects to this, of which the first was that since the boundaries had been drawn in 1885, migratory trends in mainland Britain had swollen the population not only within but also around the major cities, and nowhere more so than in the capital and its suburban sprawl - between the 1901 and 1911 censuses, the population of Middlesex increased by $42 \%$. The largest electorates were to be found in the 'home counties'; in 1910, Romford had 53,002 voters, Walthamstow had 39,117, Harrow had 35,379 and Wimbledon had 34,719, when most constituencies were in the 8,000-15,000 range and few exceeded 20,000. There was a strong case that these areas were under-represented and should be divided into a larger number of constituencies; as they were predominantly represented by Conservatives, this would almost certainly increase the party's number of MPs (as it did after 1918, see the table below). The same demographic causes had diminished the population of rural areas, especially the more remote and less prosperous. This particularly affected the border and highland regions of Scotland; they were mainly represented by Liberal MPs, and so the Liberal Party had resisted a mainland redistribution from which it was likely to be doubly disadvantaged.

The second aspect of redistribution was also inimical to the continuation of Liberal government, although in this case indirectly. This was the change in the balance of population between Ireland and mainland Britain since the Act of Union of 1800, which meant that the 100 Irish seats in the House of Commons created by that measure was now a considerable over-representation. ${ }^{56}$ Whereas in 1821 the population of Ireland had been $32.5 \%$ of the United Kingdom total, by the census of 1911 it had greatly diminished, through the combined effects of the Great Famine of 1845-51, continued emigration and changes in family structure, and Ireland now accounted for only $9.7 \% .^{57}$ In the elections from 1885 to 1910, Irish Nationalist MPs were returned for between 80 and 85 of the seats, and this over-representation of Ireland had benefitted the Liberal Party ever since Gladstone's adoption of Home Rule as Liberal policy in 1886. After the 1910 elections, in which the Conservatives and Liberals won almost the same number of seats, to Conservative fury it was Irish Nationalist support - even more than the much smaller Labour Party - which had maintained the Liberal government in office and enabled it to crush the power of the House of Lords in the 1911 Parliament Act and embark on the disestablishment of the Anglican church in Wales and, worst of all, a Home Rule Bill that would now reach the statute book.

In this context, Conservatives considered that if electoral reform was to be 'dealt with on a sound basis', 'an Equitable scheme of Redistribution ... to be applicable to the whole of the U[nited] $\mathrm{K}$ [ingdom]' was an essential element. ${ }^{58}$ This objective was only partially achieved, as although there were some changes within Ireland, the total number of Irish seats was not reduced. However, the wholesale revision of constituency boundaries in mainland Britain did substantially benefit the Conservatives, as can be seen in the table below.

Table 1: The Effects of Constituency Redistribution in the Home Counties ${ }^{59}$

This table compares the number of seats and the number won by the Conservative Party in the general

56

This became 101 seats after the creation of a second seat for Trinity College Dublin in the 1832 Reform Act, and remained at that number in the 1867 and 1884 Reform Acts.

57

Census of England and Wales, 1911: General Report, with Appendices (1917), 263, Appendix C, 'Tables Relating to the United Kingdom'.
CPA, NUA central council, 8 June 1917, 'Electoral Reform "Representation of the People Bill", Report of the Subcommittee to the Executive Committee', emphasis in the original.

59 British Parliamentary Election Results 1885-1918, ed. F.W.S Craig (1974); British Parliamentary Election Results 1918-1949, ed. F.W.S Craig (2nd edn, 1977). 
elections of December 1910 and 1922 in the four counties bordering London. The 1918 general election has not been used because the Conservative Party was then part of a coalition and did not contest a significant number of seats. Only official Conservative candidates have been counted (for 1910 this includes official Liberal Unionist candidates).

\begin{tabular}{lcccc}
\hline \multirow{2}{*}{ County } & \multicolumn{2}{c}{ December 1910} & \multicolumn{2}{c}{1922} \\
& No. Seats & No. Cons wins & No. Seats & No. Cons wins \\
\hline Essex & 11 & 6 & 20 & 13 \\
Kent & 15 & 12 & 15 & 14 \\
Middlesex & 7 & 6 & 17 & 14 \\
Surrey & 7 & 7 & 12 & 11 \\
\hline TOTAL & 40 & 31 & 64 & 52 \\
\hline
\end{tabular}

In Scotland, the disappearance of the smaller 'district of burghs' type of constituency through merger into their surrounding county divisions was more often than not to Conservative advantage. ${ }^{60}$ In one notable example, it contributed to the defeat of Asquith in the enlarged East Fife constituency in 1918. ${ }^{61}$ Overall, it has been suggested that the Conservative Party made a net gain of around 30 seats from the redistribution. ${ }^{62}$

It has also been argued that the number of safe Conservative seats increased, as more constituencies had a substantial element of their population that was either middle-class or engaged in agriculture. Two hundred constituencies had $20 \%$ or more of their occupied male population in the census categories used by Michael Kinnear to identify the middle class, although the accuracy of the calculation is affected by the insoluble problem that census data exists only for each borough as a whole, and not for the individual constituencies within a divided borough. ${ }^{63}$ Thus the city of Manchester, which comprised ten single-member constituencies, had 23.3\% middle class population as a whole, and so all ten seats are included in Kinnear's total - of course, the middle class voters were not evenly distributed across the city, with some divisions having more and others less. As that cannot be identified statistically there is no alternative to this rather crude methodology, but it is more likely that the actual number of seats with a middle class population of more than $20 \%$ was around 150 to 160. There were also 86 county constituencies with more than $30 \%$ of their occupied male population engaged in agriculture. The Conservative Party won most of these seats in every general election apart from 1923, when the Liberals won 43 and the Conservatives 38; however, with the Liberal decline after this, the Conservatives won 74 in 1924, and even in defeat in 1929 they won 55. ${ }^{64}$ Whilst being very highly agricultural did not always correlate with Conservative success, as several of the most agricultural seats had a strong Nonconformist and Liberal tradition, nevertheless the

60 M. Dyer, 'Burgh districts and the representation of Scotland, 1707-1983', Parliamentary History, xv (1996), 302-4; M. Dyer, Capable Citizens and Improvident Democrats: The Scottish Electoral System, 1884-1929 (Aberdeen, 1996), 107-12.

61 Bodl., Asquith MSS, 33/25, A. Birrell to H. Asquith, 28 Dec. 1918, 33/60, J. Hogge to Asquith, 30 Dec. 1918 ; S. Ball, 'Asquith's decline and the general election of 1918', Scottish Historical Review, 1xi (1982), 44-61.

62 Ramsden, Age of Balfour and Baldwin, 123; Keohane, Party of Patriotism, 146-53.

63 M. Kinnear, The British Voter: An Atlas and Survey since 1885 (2nd edn., 1981), 122-4.

64 Kinnear, British Voter, 119-21. For evidence of the role of agriculture in Conservative support between the wars, see Ball, Portrait of a Party, 112, table 2.7. 
Conservative Party could count most of rural England and much of rural Scotland amongst its bedrock, and increasingly so after 1929.

Taking together the seats with significant middle-class and agricultural sectors, John Ramsden concluded that in the inter-war period 'well over 200 seats [were] unshakably safe', and as many as 300 were 'reliable enough to be won except in a very bad year'. ${ }^{65}$ With the house of commons reduced to 615 seats after the Anglo-Irish treaty of 1921, the advantage of such a solid base was clear - not only in winning general elections but also in defeats, when the Conservatives were able to prevent the Labour Party from gaining an overall majority. However, although the redistribution is often discussed in terms of conferring an advantage on the Conservatives, it would be more accurate to say that it removed a disadvantage which they had suffered in the pre-war years and broadly restored a level playing-field. Of course, the same demographic trends continued, and twenty years further on it was again the home counties which had constituencies with excessively large electorates and their Conservative MPs who were pressing the National Government in 1937-38 to take steps to remedy the situation before the next election, as once again 'we as a Party are placed under a considerable disadvantage'. 66

A more immediate impact of the boundary changes was to stimulate in 1917-18 a revival of the local constituency associations, many of which had lapsed into inactivity since the early part of the war, with their leading figures and professional agents away on military service or absorbed into the expanded wartime bureaucracy. ${ }^{67}$ This occurred in two stages, the first of which was in response to the proposals of the boundary commissioners, in attempts to avoid changes that would be detrimental to Conservative prospects. The party headquarters in London often advised and supported these efforts, but they were primarily local in origin, and a logical case based upon local topography and traditions could influence the boundary commissioners when they visited the localities. The second stage followed from the enactment of the new arrangements, for as legal entities the associations for the former constituencies had to be dissolved, which entailed winding up their financial affairs, and new associations established. ${ }^{68}$ In some places, where the extent of the constituency remained broadly similar, this was a fairly nominal and straightforward evolution from the old association, with the new inheriting its funds, premises and staff, and continuing under the same leadership. ${ }^{69}$ In others, where the core of a former constituency - often a moderate-sized borough - gained an accretion of outlying districts, it was a case of transferring the branches for these areas from their previous parent body and giving them a share of representation on the central committees of the new association. ${ }^{70}$ The most difficult category was where constituencies disappeared and radically new ones replaced them, and it was here most of all that the frictions of personal ambition and status and of local particularism or

65 Ramsden, Age of Balfour and Baldwin, 123. For a statistical analysis of the middle class correlation with Conservative support in the inter-war period, see Ball, Portrait of a Party, 109-111.

66 TNA, PREM 1/255, Sir A. Pownall to the Prime Minister, 13 Feb., 16 June 1937, 13 May 1938. In the 1935 general election, supporters of the National Government (mostly Conservatives) represented 44 of the 48 seats with the largest electorates.

67 Ramsden, Age of Balfour and Baldwin, 124-5; Yorkshire Area, council, 'Report for the six months ending the 30th of June 1917', 'Redistribution Meetings'.

These constituencies also generally continued using the same minute book, whilst in other cases these were passed on to the successor constituency, such as Strand CA, 1886-1918, in St. George's CA deposit (Westminster City Library, 487/5); Mid-Kent CA, 1885-1918, in Maidstone CA deposit (Kent History \& Library Centre, U1634); Suffolk North-West CA, 1893-1917, in Bury St. Edmunds CA deposit (Suffolk Record Office, GK501); Truro \& Helston CA, 1908-16, in Penryn \& Falmouth CA deposit (Cornwall Record Office, X.551/10), North West Norfolk CA, 1897-1918, continues after merger as King's Lynn CA (North West Norfolk CA); see S. Ball, 'National politics and local history: the regional and local archives of the Conservative Party 1867-1945', Archives, 22 (1996), 48-9, and for specific details, S. Ball, A Summary List of the Regional and Local Records of the Conservative Party 18671945, unpublished list deposited at the Conservative Party Archive. 
resentments could cause difficulties. An example of all these elements occurred in the new Shrewsbury constituency, which was a merger of the former Shrewsbury borough seat and parts of three neighbouring county divisions. At the first meeting to organise the new association, two candidates were proposed as chairman, one from a county district and the other the former chairman of the borough seat; rather than having a vote, the latter suggested settling the question with the toss of a coin, which he lost. However, at the next meeting a letter was received from him declaring that the borough association had decided to withdraw from the merger and proposing two separate associations in the constituency, one for the town and the other for the rest. This was obviously impracticable, but unity was only achieved by revisions of the proposed new rules and by the chairman from the county stepping down in favour of the former borough chairman. ${ }^{71}$

The effects of the 1918 Reform Act on the Conservative Party were felt not only in the immediate wake of its passage, but also in the decade (and decades) that followed. The victorious outcome of the December 1918 general election gave some reassurance, although the increase in the Labour vote and the low turnout of $57.2 \%$ were matters of concern. One aspect which stood out was that women had voted in substantial numbers, and mainly for the Coalition candidates; in the industrial town of Rotherham, as in many other places, the "womens franchise had helped to secure success'. ${ }^{72}$ This pattern was to continue, and by the time of the next general election the view of party headquarters was 'that the larger the poll of women voters the better it would be for the Conservatives'. ${ }^{73}$ After 1918, the party made sustained efforts to adapt its structures and methods, and to reach not only the women but also the other main categories of new voters. However, these were developments of existing institutions and were changes of scale rather than of function. This was particularly the case with the expansion of the representative bodies of the party membership; after an overhaul of the rules in 1924, the average attendance at the central council rose from the pre-war figure of 102 to 681 in the period 1925-39, whilst by 1929 the attendance at the annual conference had reached almost four thousand. $^{74}$ The party's other response to the enlarged electorate was the development of new methods of communication and campaigning to reach a mass audience. More emphasis was placed on propaganda, mainly through leaflets, and the party made its own propaganda films which were shown around the country by a fleet of cinema vans, which were especially effective in rural areas. ${ }^{75}$

The party chairman moved rapidly after the passage of the Representation of the People Act to encourage women's participation and integrate them into the organisation. In April 1918 the rules of the National Unionist Association were adapted to admit women to membership of the executive committee and central council, and Younger negotiated the transformation of Women's Amalgamated Unionist and Tariff Reform Association, with before the war had been a large and active campaigning body outside the formal party structure, into a vital constituent element within it, under the new name

71 Shrewsbury CA, first meeting, 23 Feb., provisional committee, 4 May, meeting of deputations, 1 June, provisional committee, 8 June 1918.

72 Rotherham CA, annual general meeting, 12 May 1919; Hampshire Record Office, 114M84/1, Aldershot CA, executive committee, 6 Feb. 1919; Derby MSS, 920/DER(17)/20/1, P. Woodhouse to earl of Derby, 1 Jan. 1919.

73 Daily Telegraph, 2 Nov. 1922, 11.

$74 \quad$ Ball, Portrait of a Party, 248-9, 254.

75 A. Taylor, 'Speaking to democracy: the Conservative Party and mass opinion from the 1920s to the 1950s', in Mass Conservatism: The Conservatives and the Public since the 1880s, ed. S. Ball \& I. Holliday (2002), 78-85; T.J. Hollins, 'The Conservative Party and film propaganda between the wars', English Historical Review, xcvi (1981), 359-69. 
of the Women's Unionist Organisation. ${ }^{76}$ This now had a supporting staff housed within the party headquarters, which grew in number during the following decade. The effectiveness of these national developments mutually reinforced the rapid expansion of women's membership in the constituencies, especially in the suburbs, small towns and countryside. ${ }^{77}$ By the summer of 1920, the agent at Weymouth was reporting that more women than men had attended his association's annual general meeting; in a typical example, one Somerset county division had grown to 50 local women's branches with a claimed membership of over 4,000 by the end of $1924 .^{78}$ A preponderance of female membership became the common pattern at local level in the inter-war period, and in the safer seats particularly this could be as large a ratio as four times the number of men. The claims in the later 1920s that the party had a million women members may have been inflated, but not greatly, and the true figure was probably between 750,000 and one million. ${ }^{79}$ This large female membership, which included many middle-class women with time and energy available for voluntary activities, was very useful given the need for more party workers due to the combination of the larger electorate and the reduced limit on election expenses. ${ }^{80}$

Younger also devoted much effort, but with less reward, to create a new wing of the party organisation aimed at male working-class trade unionists. ${ }^{81}$ The Unionist Labour Movement developed from some active pre-war 'labour' organisations in Lancashire, and for that reason held its inaugural conference at Southport on 6 March $1920 .^{82}$ It was never able to recruit on a large scale, and remained more of a sounding board than a campaigning asset. Younger and his successors as party chairman also encouraged constituencies to establish their own Labour Advisory Committees, but this tended to happen only in areas where Labour and trade unionism was strong, and consequently to have little effect. ${ }^{83}$ The third organisational initiative in response to the extension of the franchise bore more fruit. This was the creation of a youth movement, which similarily to the women's organisation was established by integrating an existing separate body into the structure of the party at every level from local branches in constituencies to its own regional committees, national executive and annual conference. ${ }^{84}$ The Junior Imperial League had been founded by Henry Imbert-Terry in 1906 for men aged 18 to 30, most of whom would not have been voters under the pre-war franchise. Having lapsed during the war as its members were engaged in war work, it was revived in 1920 and now admitted female members. Its expansion was further encouraged by the party chairman from 1926 to 1930, J.C.C. Davidson, partly in response to the equalisation of the franchise in 1928. It proved popular as

76 CPA, NUA executive, 21 Jan., 9 July 1918, NUA central council, 11 Mar. 1919; N.R. McCrillis, The British Conservative Party in the Age of Universal Suffrage: Popular Conservatism 1918-1929 (Columbus, 1998), 20-2; Keohane, Party of Patriotism, 157-60.

77 For the development of the women's organisation after 1918, see Ball, Portrait of a Party, 153-4, 167-8, 245, 268-9; Maguire, Conservative Women, 73-93; McCrillis, Conservative Party in the Age of Universal Suffrage, 22-4, 46-82; D. Thackeray, 'Home and politics: women and Conservative activism in early twentieth-century Britain', Journal of British Studies, 49 (2010), 836-8, 845; N. Fleming, 'Women and Lancashire Conservatism between the wars', Women's History Review, 26, no. 3 (2017), 329-49.

Conservative Agents' Journal, July 1920, 17; Wells CA, finance committee, agent's report, 9 Dec. 1924.

Ball, Portrait of a Party, 167-8.

Edinburgh City Archives, Acc. 198/11, Edinburgh North CA, agent's report to executive committee, 30 Oct. 1918.

For the development of the trade unionist organisation after 1918, see Ball, Portrait of a Party, 157-60, 245, 289, 269-70, 289; J. Greenwood, The Conservative Party and the Working Classes: the Organisational Response (Warwick, 1974); McCrillis, Conservative Party in the Age of Universal Suffrage, 110-44.

Conservative Agents' Journal, Apr. 1920, 15, May 1920, 5-9.

Conservative Agents' Journal, Mar. 1920, 1-5.

84 Conservative Agents' Journal, Dec. 1920, 17-20, Mar. 1921, 11-15. For the development of the youth organisation after 1918, see Ball, Portrait of a Party, 154-7, 288-9; McCrillis, Conservative Party in the Age of Universal Suffrage, 83-109. 
a respectable way for young men and women to meet, and like the women's movement much of its activity was in social events; by 1930 its national membership was between 150,000 and 200,000.

The nature of local political activity changed after 1918 due to the huge increase in the electorate and the simplification of the registration system. This particularly affected the work of the professional party agents; in the complicated previous system, they had principally focused upon canvassing to identify the party allegiance of voters, the compilation of the register and the annual battle of the revision courts. In the smaller pre-1918 electorates, getting two or three hundred of your own marginally-qualified voters onto the register and successfully objecting to a similar number of your opponent's could swing the balance in many constituencies, and 'elections were won in the Revision Courts'. ${ }^{85}$ After 1918, the straight-forward nature of the residential qualification meant that there was little need to substantiate claims to the franchise and fewer opportunities for objections, whilst the neutral efficiency of the local government officials who now oversaw the register meant that few voters were omitted (apart from some problems with the first registers in 1918). The consequence was that making a regular thorough canvass of the voters was impracticable due to their number and no longer the most productive use of the time and resources available, and as early as 1921 one agent noted the 'growing tendency to ignore registration'. ${ }^{86}$ Instead, during the 1920s the activities of local agents and their constituency associations moved towards campaigning, propaganda, recruitment and fund-raising. ${ }^{87}$ This process was further encouraged by the 1918 Reform Act's limits on election expenditure, which allowed much less per voter than before, at the same time as costs had risen due to the wartime inflation. In combination with the massive expansion of the electorate, as an experienced local Conservative agent observed in 1920, 'all this entails a complete re-casting of the electoral machinery'. ${ }^{88}$ It also accelerated the changes that were developing in the Conservative agents' profession, as their work ceased to be mainly legal, and thus often carried out on a part-time basis by a local solicitor, and became instead organisational and managerial, and increasingly a full-time occupation with its own career structure and recognised qualification.

The expansion of the franchise in 1918 had an impact on the role and responsibilities of being a member of parliament. Whilst this affected all parties, it had particular consequences for the Conservatives; firstly, because they had - or felt - a more evident need than Labour MPs to demonstrate their concern for, and practical engagement with, the needs of the ordinary citizen, and secondly, because the party's success in most elections resulted in a considerable number of Conservative MPs defending vulnerable majorities in urban and industrial constituencies. The period after 1918 saw a substantial increase in the demands of constituency casework due to the confluence of franchise extension with three other factors: the legacy of the war in claims for disability and widows' pensions, the expanded responsibilities of local and national government, and the growth in legislation and regulation; whereas in 1906-13 the sessional volume of statutes averaged 355 pages, by 1929-38 it had reached 995 pages. ${ }^{89}$ Constituents thus placed greater demands on, and had greater expectations of, their member of parliament. ${ }^{90}$ These were partly conflicting: the MP should be an assiduous attender of the House, asking questions and taking part in divisions; an effective and persistent communicator of constituents' cases and claims to Whitehall ministries and local town halls, and also increasingly an active local presence - regular visits and speech-making became the norm,

85

86

Conservative Agents' Journal, Aug. 1919, 2.

Conservative Agents' Journal, Sep. 1921, 1-3. An article contributed by a local agent in 1923 shows that considerable work had resulted in a net gain on the register of 152 voters, which in most constituencies was less than 0.3\% of the electorate: Conservative Agents' Journal, Nov. 1923, 253.

Ball, Portrait of a Party, 174, 191-3.

Conservative Agents' Journal, Sep. 1920, 15.

S. Ball, 'Parliament and politics in Britain 1900-51', Parliamentary History, x (1991), 250, 265-6.

Sir H. Brittain, Happy Pilgrimage (not dated, but 1949), 48; Brittain became MP for Acton in 1918. 
and there were fewer places where a brief annual speaking tour was still sufficient. ${ }^{91}$ Concern about the expectations of the democratic electorate and the need to find their feet quickly and demonstrate effectiveness was the principal motivation for a number of the Conservative MPs who were first elected in the 1922 general election to form a self-help group, 'the Conservative Private Members' (1922) Committee'. ${ }^{92}$ Such was the utility of this forum that by 1926 it had expanded to include all Conservative backbenchers irrespective of when they had entered the House, an evolution which led to the 1922 Committee becoming a permanent institution which has long outlived its founders.

The 1918 Reform Act gave further stimulus to the vexed question of the reform of the House of Lords, as was underlined when the central council resolution of April 1917 which declared 'strongly in favour of an extension of the franchise' explicitly linked this with 'the absolute necessity of concurrently establishing a reformed Second Chamber possessed of adequate powers'. ${ }^{93}$ The Conservatives sought to hold the pre-war Liberal government and its coalition successors to the promise made in the preamble to the 1911 Parliament Act of further reform, which they took to mean a reappraisal of the upper house that would strengthen its powers, not diminish them further. ${ }^{94}$ This was no theoretical aspiration, for with the advance of the Labour Party and the alarming signs of industrial militancy between 1917 and 1922, the need for a second chamber that could act as an effective barrier to the depredations of a possible Socialist majority in the House of Commons seemed ever more necessary to the Conservative grass-roots and many backbench MPs - the upper chamber's present capacity for resistance being limited to delaying a bill for up to two years, and financial bills not at all. Conservatives envisaged conceding changes in the composition of the House of Lords that would make it a broader and more representative institution, so that it would not seem provocatively anti-democratic to restore some of its powers. The Conservatives made several attempts during the inter-war period to find an acceptable formula for second chamber reform, but all of these foundered between the twin rocks of the fear of appearing reactionary and encouraging class hostility on the one hand, and on the other the reluctance of MPs to cede power to the upper chamber, especially if it should acquire rivalling legitimacy through being transformed into an elected senate or even having a significant elected component. ${ }^{95}$ However, this left the vulnerable breach in the constitution unfilled, and in the early 1920 s the dangers seemed so great that the demand for second chamber reform became the one of most extensive, persistent and urgent concerns of the Conservative constituencies, and this was repeatedly expressed through the executive committee, central council and annual conference of the National Union. ${ }^{96}$

The disappointment of Conservative right-wing MPs and the party's grass-roots more generally at the failure of their leaders to grasp the nettle of second chamber reform was augmented by the Representation of the People (Equal Franchise) Act of 1928, which substantially expanded the female

91

National Library of Wales, Brogyntyn MSS, PEC/10/1/11/15, W. Ormsby-Gore to his mother, 15 Nov. 1919.

S. Ball, 'The 1922 Committee: the formative years 1922-45', Parliamentary History, ix (1990), 130-3.

CPA, NUA central council, 17 Apr. 1917.

For discussion of this issue, see Ball, Portrait of a Party, 388-90; D.H. Close, 'The collapse of resistance to democracy: Conservatives, adult suffrage, and Second Chamber reform 1911-1928', Historical Journal, xx (1977), 893-918; N.R. McCrillis, 'Taming democracy? The Conservative Party and House of Lords' reform 1916-1929', Parliamentary History, xii (1993), 259-80; G. Thomas, 'Conservatives, the constitution, and the quest for a "representative” House of Lords 1911-1935', Parliamentary History, xxxi (2012), 419-43.

95 Warwick University Library, Leslie Scott MSS, 119/3/5/CO/3-4, secretary's notes of a meeting between the Cabinet House of Lords Reform Committee and a deputation from the executive committee of the Second Chamber Committee of Conservative MPs, 7 Dec. 1925; Headlam diary, 12 \& 20 May, 10 June, 16 Dec. 1925, 27 June, 6 July 1927, 28 Mar. 1932, in Parliament and Politics in the Age of Baldwin and MacDonald: The Headlam Diaries 19231935, ed. S. Ball (1992), 62-5, 75, 125-6, 234; A.D. Cooper \& C.M. Headlam, House of Lords or Senate? (1932).

CPA, NUA executive, 13 Apr., 12 Oct. 1920, 8 Mar. 1921, 11 May 1922; NUA central council, 11 Mar., 20 May 1919, 23 Feb., 21 June 1921, 27 June 1922; PA, Bonar Law MSS, BL/96/2, Younger to Bonar Law, 3 Jan. 1920, BL/100/2/30, Younger to Bonar Law, 23 Feb. 1921. 
electorate by putting the qualification on the same basis as that for men. Although it was widely accepted that the age compromise in the 1918 Reform Act could only be temporary and that eventually equalisation was inevitable, ${ }^{97}$ many Conservatives were reluctant to take this final step towards full adult suffrage. This was due not to any remaining hostility to the principle of women's inclusion but to the age range of the new female voters, who were often assumed to be inexperienced, impulsive and easily influenced by emotional appeals. In general, by the mid-1920s women voters were welcomed by Conservatives for their contribution to political stability, and this together with the desire to avoid appearing reactionary contributed to Bonar Law's personal endorsement of franchise equalisation in the 1922 general election and Baldwin's more definite statement during the 1924 election campaign that the party was 'in favour of equal political rights for men and women'. ${ }^{98} \mathrm{He}$ proposed that the question be examined by an inter-party conference on the model of 1916, but when the Conservatives were returned to office this was not an immediate priority, partly because of the convention that any franchise extension should come near the end of a parliament's life in order soon to be followed by an election on the new basis. However, a crucial exchange occurred in the house of commons on 20 February 1925, when the home secretary, Sir William Joynson-Hicks, moved the rejection of a Labour MP's private members' bill to give women the vote on the same basis as men. Joynson-Hicks promised legislation 'within the lifetime of the present Parliament' on the basis of Baldwin's pledge, when he was interrupted by a question from the Conservative MP, Lady Astor, asking if he meant equal votes at the age of 21 . The home secretary's response was: ${ }^{99}$

\footnotetext{
It means exactly what it says. ... The Prime Minister's pledge is for equal rights and at the next election. I will say quite definitely that means no difference will take place in the ages at which men and women go to the polls at the next election.
}

Joynson-Hicks was known for his impulsiveness, and because of this and the fact that Baldwin had been sitting beside him on the front bench and had not demurred, it was taken by everyone that he had committed the government to equalisation at 21; in fact, he had left the question of the age open and had only - and uncontroversially - reaffirmed the principle of equality.

However, his cabinet colleagues, somewhat aggrieved at the perceived lack of consultation, considered that he had sold the pass and put them in a position from which they could not honourably retreat. The leader of the party in the house of lords, Lord Salisbury, echoed the general acceptance that a change from 30 was inevitable, but pessimistically concluded that equalisation at 21 'is going to do us a lot of harm now - though hereafter it may possibly pay'. ${ }^{100}$ The reason for his concern was the very vocal pressure from the party grass-roots, shared by many MPs and strongly supported by the Daily Mail, for a voting age of 25 for both men and women. ${ }^{101}$ This was based partly on a crude stereotyping of the younger women as foolish and irresponsible 'flappers', and partly on the more realistic perception that most working-class women under 25 were in employment and more susceptible to the appeal of the Labour Party - this was the basis of the advice from the party chairman and Central Office 'that equal franchise at 21 would prejudice the Party in industrial areas'. ${ }^{102}$

97 Daily Telegraph, 13 Mar., 10, and 30 Mar. 1928, 10.

98 The Times, 11 Nov. 1922, 12, and 18 Oct. 1924, 12.

$99 \quad H C D e b$. , fifth series, clxxx, col. 1479, 1503-4, 20 Feb. 1925.

100 Marquis of Salisbury to Lord Irwin, 24 April 1927, Conservative Politics in National and Imperial Crisis: Letters from Britain to the Viceroy of India 1926-1931, ed. S. Ball (Farnham, 2014), 135.

101 G. Lane-Fox to Lord Irwin, 28 April 1927, Conservative Politics in National and Imperial Crisis, 137; Ball, Portrait of a Party, 229-30; A. Bingham, "'Stop the Flapper Vote Folly": Lord Rothermere, the Daily Mail, and the Equalization of the Franchise 1927-28', Twentieth Century British History, xiii (2002), 17-37; Close, 'Collapse of resistance to democracy', 915-17.

102 TNA, CAB 27/336, equal franchise committee, 21 Feb. 1927, 2 \& Appendix i. Not all Conservatives were opposed: the delegate who moved a resolution in support of equalisation at 21 at the 1927 annual conference objected to the "plethora of abuse ... such as "Votes for flappers" and they ought to protest against such an offensive term being applied to women of twenty-one, tens of thousands of whom were married and blessed with families', and in the 
However, despite the chorus of support for equalisation at 25 , its consequence of denying the vote to the estimated two and a half million men aged 21 to 24 was too damaging. ${ }^{103}$ Taking away a franchise once given was seen as too reactionary and anti-democratic, and the gain would be too small to be worth the penalty of alienating those who within a short period would gain the vote at the higher age anyway. After three meetings of a sub-committee which considered various forms of equalisation, the full cabinet decided in April 1927 to proceed with legislation to equalise the franchise at 21, and this was passed in July $1928 .^{104}$

The increase in the number of women on the register between 1928 and 1929 has been calculated as 5,299,301, which was $18.4 \%$ of the electorate at the general election in May $1929 .{ }^{105}$ By this time, the tide of public opinion was flowing away from the Conservative government. Its final eighteen months had contained little to arouse enthusiasm: middle-class hopes for substantial reductions in spending and taxation had been impossible to fulfil; unemployment had remained stubbornly high; agriculture was in severe depression; the Labour Party had strengthened its position since 1924 and had an attractive programme, and the Liberal Party had been revived by Lloyd George with money (if of dubious origin) and economic plans (if of dubious practicality), whilst from the Conservative local associations came reports of widespread apathy. All of this would have led to defeat even if there had been no equalisation of the female franchise, but many Conservatives chose to give it the lion's share of the blame, together with the Liberal revival. ${ }^{106}$ Its actual effect is harder to determine, especially as the pre-disposition of many Conservatives may have led them to see what they had expected. The majority of views were negative, such as in the industrial city of Dundee where it was thought that $80 \%$ of the new votes had gone to Labour, ${ }^{107}$ but on the other hand, the experienced former party chairman and only cabinet minister to lose his seat, Sir Arthur Steel-Maitland, considered 'particularly that the "flapper vote" did not influence matters in the least." 108 What can be said is that when the other contingent circumstances changed, full adult suffrage for both genders did not prevent Conservative electoral victories in 1931, 1935 and after 1945.

In the form that finally reached the statute book, the Representation of the People Act of 1918 was, as Ross McKibbin has argued, 'the most conservative piece of legislation that could have been devised in the circumstances'. ${ }^{109}$ The war had made adult male suffrage both unavoidable and less alarming, the almost-equally unavoidable accompaniment of female suffrage had been limited by age and to a lesser extent property in ways beneficial to the Conservatives, plural voting had been retained although reduced, the threat posed by proportional representation had been avoided, and the underrepresentation of the areas of Conservative support around London had been corrected. Whilst the

same debate Ian Fraser MP pointed out that one-third of those who would be enfranchised were over 30 and onethird aged 25-30; the resolution was carried 'with loud acclamation': CPA, NUA/2/1/43, NUA conference, 6-7 Oct. 1927.

Daily Telegraph, 19 Apr. 1928, 10; Butler, Electoral System, 33.

TNA, CAB 27/336, equal franchise committee, 15 Dec. 1926, 14 and 21 Feb. 1927; earl of Birkenhead to Lord Irwin, 13 April 1927, Conservative Politics in National and Imperial Crisis, 132.

Butler, Electoral System, 145.

See the analysis of constituency responses on the causes of defeat in S. Ball, Baldwin and the Conservative Party: The Crisis of 1929-1931 (London \& New Haven, 1988), Appendix i, 220-1.

Baldwin MSS, 37/204, E. Wallace to Baldwin, 12 June 1929. The local chairman in another Labour area 'considered the flapper vote went against us', and perhaps it was more likely to do so in such environments: Gloucestershire Archives, D7411, Forest of Dean CA, executive committee, 29 July 1929.

Steel-Maitland MSS, GD193/120/3/212, Steel-Maitland to Swaby, 10 July 1929.

R. McKibbin, Parties and People: England 1914-1951 (Oxford, 2010), 27. 
advent of full male suffrage and the inclusion of another large new element in the female voters required the reappraisal of existing methods and structures, the Conservative Party proved more able to respond to the challenges and take advantage of the opportunities than its hitherto main rival, the Liberals. In response to the expansion of the electorate and the rise of the Labour Party, after 1918 the Conservative Party made effective efforts to adapt its organisation, expand its membership and broaden its appeal.

Despite continuing concerns over the ignorance of the mass electorate and its potential receptiveness to demagogic and despoilatory appeals, ${ }^{110}$ in the two decades after the 1918 Reform Act the Conservative Party was able to attract substantial support from both new voters and old. The Conservatives won more seats than any other party in every general election from 1918 to 1935 with the single exception of 1929 , when they still polled 285,000 votes more than Labour. There was a 'franchise factor' in this record of success, in which the inclusion of women voters certainly played an important part - although it should not be accorded too prominent a role. From the early 1920s, the Conservative Party projected an effective appeal to 'the man in the street' (a category which encompassed both working men and the white-collar lower middle class), based upon national solidarity over class conflict, patriotism and pride in the empire, the defence of property (which need not be large), anti-Socialism and moderate social reform. ${ }^{111}$ Under generally moderate and cautious leadership, the Conservative Party prospered in the new environment, grew in confidence, and eventually came to embrace it. The response of the electorate in giving the National Government an overwhelming mandate after the economic crisis of 1931 settled most remaining fears, ${ }^{112}$ so that by the late 1930s 'democracy' had become something of which to be proud and to defend. ${ }^{113}$ After 1918, the internal culture of Conservatism absorbed the self-image later expressed by one young army officer during the Second World War, that 'the tradition of the Conservative Party is to win the people's trust by putting its trust in the people', ${ }^{114}$ and this had become so entrenched that the landslide defeat of 1945 could shake it.

110 This was a particular concern of Baldwin and a frequent theme in his speeches; see P. Williamson, Stanley Baldwin: Conservative Leadership and National Values (Cambridge, 1999), 203-12.

Ball, Portrait of a Party, 82-93, 106-121, 507-512. In 1937 the party's central council passed a resolution defining its 'fundamental and inseparable principles' as 'empire unity, social progress and constitutional democracy': NUA central council, 23 Mar. 1937. MPs; the National Government as a whole received $67.7 \%$ of the poll and won 558 seats.

113 For example, see the final two collected volumes of Baldwin's speeches: S. Baldwin, This Torch of Freedom (1935), 39, 51, An Interpreter of England (1939), 45. 